\title{
PEMBERDAYAAN KARANG TARUNA DESA SETONO MELALUI PEMBUATAN WOODEN HOME DECORATION
}

\author{
Mila Eviana1), Viken Alfi Tania1), Richa Firial'2), Saristi Widiyaningrum³), \\ Wachidatul Linda Yuhanna ${ }^{2)}$ \\ 1)Program Studi Manajemen, FEB, Universitas PGRI Madiun, Madiun, Jawa Timur, Indonesia \\ 2) Program Studi Pendidikan Biologi, FKIP, Universitas PGRI Madiun, Madiun, Jawa Timur, Indonesia \\ 3)Program Studi Pendidikan Fisika, FKIP, Universitas PGRI Madiun, Madiun, Jawa Timur, Indonesia \\ Corresponding author : Wachidatul Linda Yuhanna \\ E-mail : linda.yuhanna@unipma.ac.id; milaevianna@gmail.com
}

Diterima 24 Juli 2021, Direvisi 01 Agustus 2021, Disetujui 02 Agustus 2021

\begin{abstract}
ABSTRAK
Pandemi Covid19 membawa tantangan tersendiri bagi masyarakat dalam meningkatkan perekonomian. Salah satu upaya yang bisa dilakukan adalah dengan merintis usaha kreatif. Desa Setono mempunyai dua tempat penggergajian kayu yang menghasilkan limbah bilah kayu. Potensi ini dapat digunakan sebagai rintisan industri kreatif berbasis pengolahan limbah. Tim Program Kreativitas Mahasiswa Pengabdian Masyarakat (PKM-PM) mengadakan pelatihan pembuatan wooden home decoration dari limbah kayu kepada karang taruna Desa Setono. Kegiatan ini dilakukan pada bulan Juni 2021. Peserta sejumlah 10 orang. Metode yang digunakan adalah partisipatif dengan pendekatan sosial masyarakat. Hasil pelatihan menunjukan bahwa limbah penggergajian kayu dapat digunakan menjadi wooden home decoration. Produk yang dibuat sebanyak 7 model yang bernilai jual tinggi dan tidak mengganggu lingkungan. Pemberdayaan karang taruna Desa Setono dalam membuat wooden home decoration dari limbah pengergajian kayu berjalan lancar dan kondusif. Pemahaman peserta dalam membuat wooden home decoration dari limbah penggergajian kayu meningkat sebanyak $80 \%$. Tim PKM-PM akan terus melakukan pendampingan, monitoring dan evaluasi sampai bulan November 2021. Peserta berkomitmen untuk terus melanjutkan kegiatan pembuatan wooden home decoration ini, dan mengembangan bisnis industri kreatif.
\end{abstract}

Kata kunci: karang taruna; wooden home decoration; limbah kayu

\begin{abstract}
The COVID-19 pandemic brings its own challenges for the community in improving the economy. One effort that can be done is to start a creative business. Setono village has two sawmills that produce wood slats. It can be used as a model for creative industries based on waste processing. The PKM-PM team held training on making wooden home decorations from wood waste. This activity will be held in June 2021. There are 10 participants. The method used is participatory with a social approach. The results of the training show that sawmill waste can be used as a wooden home decoration. There are 7 models of products that have high selling value and do not disturb the environment. The empowerment of the Setono Village youth group in making wooden home decorations from sawmill waste went well and was conducive. Participants' understanding of making wooden home decorations from sawmill waste increased by $80 \%$. The PKM-PM team will continue to provide assistance, monitoring and evaluation until November 2021. Participants are committed to continuing this wooden home decoration activity, and developing the creative industry business.
\end{abstract}

Keywords: youth organization; wooden home decoration; wood waste

\section{PENDAHULUAN}

Pandemi Covid19 membawa perubahan pada segala sektor terutama perekonomian masyarakat. Efek pandemi mengguncang stabilitas ekonomi berupa penurunan omset, pembatasan akses, penutupan lokasi wisata, dan Pemutusan Hubungan Kerja (PHK) . Hal ini berakibat banyak masyarakat Desa Setono usia produktif yang kehilangan pekerjaan dan pengangguran. Tenaga kerja dari perkotaan seperti Surabaya dan Jakarta banyak mengalami PHK sehingga pulang ke Desa Setono dan tidak mempunyai pekerjaan. Saat ini perlu adanya pemulihan ekonomi melalui pemberdayaan masyarakat. Wibowo dkk (2020) dan Modjo (2020) menyatakan bahwa pemulihan ekonomi masa pandemi dapat dilakukan dari hal yang sederhana di lingkup keluarga dan lingkungan rumah. 
Desa Setono merupakan salah satu desa di Kecamatan Ngrambe Kabupaten Ngawi. Desa ini berjarak $46,9 \mathrm{~km}$ dari Universitas PGRI Madiun. Desa Setono mempunyai topografi berupa dataran sedang $300 \mathrm{~m}$ diatas permukaan laut. Batas Desa Setono sebelas selatan adalah Desa Giriharjo, sebelah utara Desa Dawung, sebelah barat Desa Wakah dan sebelah timur Desa Jogorogo. Luas desa setono adalah 476.470 ha. Jumlah penduduk Desa Setono mencapai angka 2.816 Jiwa. Jarak ke kecamatan sekitar $3 \mathrm{~km}$ dan jarak ke Kabupaten adalah $30 \mathrm{~km}$.

Desa Setono terdapat dua tempat penggergajian kayu yang menghasilkan limbah yang melimpah. Limbah hasil pemotongan kayu terdiri dari bilah kayu kecil dan serbuk kayu. Limbah ini belum dimanfaatkan secara maksimal. Pada musim penghujan, limbah pengergajian kayu ini menimbulkan bau yang menyengat dan membusuk. Kayu yang tidak dipakai, biasanya hanya digunakan untuk kayu bakar bagi masyarakat setempat. Limbah kayu ini jika dijual, dihargai rendah. Inovasi dan kreatifitas sangat diperlukan untuk mengolah limbah kayu ini untuk menjadi barang bernilai ekonomi.

Limbah penggergajian kayu berupa bilah kayu ini dapat dimanfaatkan menjadi produk yang bernilai jual dan berpotensi menjadi produk unggulan Desa Setono. Limbah bilah pinggiran kayu dapat dimanfaatkan menjadi souvenir yang menarik (Widayanti \& Kristiawan, 2020), mebel (Purwanto, 2009), kerajinan (Eskak, 2014), produk industry kreatif (Cahyandari, 2007) dan lampu hias (Abednego \& Pramudita, 2017).

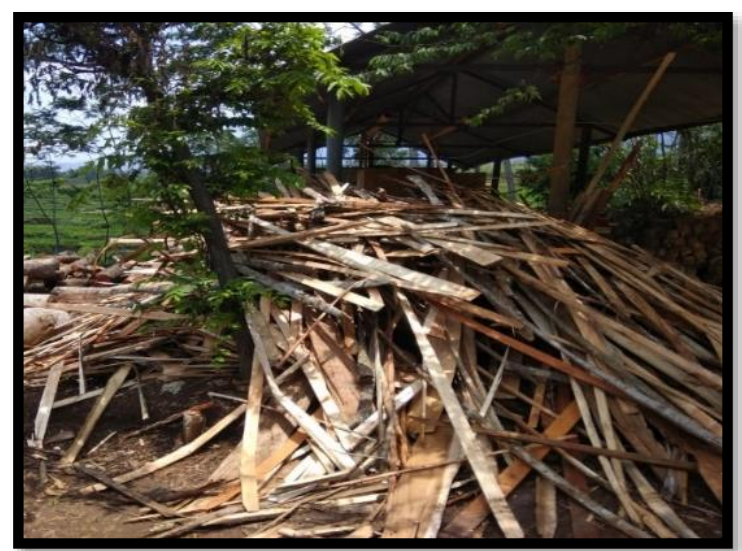

Gambar 1. Limbah Bilah kayu

Wooden Home decoration adalah seni menghias bagian dalam rumah dengan berbagai ornamen dan hiasan yang memberikan efek nyaman bagi penghuninya. Salah satu produk Wooden Home Decoration dari bahan kayu adalah vas, rak hexagon, rak dinding, rak bunga, meja dan kursi. Wooden
Home Decoration juga banyak dicari oleh pemilik cafe, hotel, restoran dan fotografi sebagai pendukung dekorasi yang artistik. Pengolahan limbah untuk interior harus memperhatikan kreativitas, desain dan nilai estetikanya (Widayanti \& Kristiawan, 2020). Dekorasi interior juga dapat berupa kursi, lukisan dan boneka kayu. Limbah kayu juga dapat digunakan sebagai pelapis interior dan eksterior (Janah, 2019) dan pembuatan blok (Purwanto, 2011)

Pengolahan limbah menjadi barang yang bernilai jual dapat dilakukan dengan memberdayakan masyarakat produktif. Pemberdayaan masyarakat adalah upaya untuk meningkatkan potensi individu dalam mengolah sesuatu (Rochayati et al., 2018). Konsep pemberdayaan masyarakat mengacu pada konsep pembangunan ekonomi dengan memperhatikan nilai-nilai sosial (Wahyudi Arfianto \& U. Balahmar, 2016).

Saat ini pengembangan ekonomi kreatif dari sektor art decoration dan tanaman hias sangat banyak diminati (Farida dkk, 2020). Industri kreatif merupakan sebuah kegiatan ekonomi yang terkait dengan menciptakan atau penggunaan pengetahuan dengan memanfaatkan ide atau inovasi dari seseorang (Arifianto et al., 2018). Tren Wooden Home Decoration dan tanaman hias menjadi peluang bisnis yang menarik dengan melibatkan karang taruna dan masyarakat usia produktif yang tidak bekerja. Produk ini juga dapat menjadi produk wisata di Kabupaten Ngawi.

Adanya potensi limbah penggergajian kayu ini dapat menjadi peluang bisnis di bidang industri kreatif untuk memulihkan perekonomian masyarakat usia produktif khususnya karang taruna yang tidak bekerja akibat pandemi Covid19. Tujuan program pemberdayaan masyarakat ini adalah 1) Mengolah limbah penggergajian kayu menjadi Wooden Home Decoration yang bernilai jual tinggi dan tidak mengganggu lingkungan serta berpotensi menjadi produk unggulan Desa Setono. 2) Meningkatkan pengetahuan dan keterampilan karang taruna Desa Setono dalam membuat Wooden Home Decoration dari limbah pengergajian kayu

\section{METODE}

Kegiatan ini dilakukan di Desa Setono Kecamatan Ngrambe Kabupaten Ngawi Jawa Timur pada Bulan Juni 2021. Sasaran dari PKM-PM ini adalah karang taruna putra sejumlah 10 orang. Jumlah ini sesuai dengan arahan dari kepala Desa Setono selama PPKM di era Pandemi Covid19. Tim PKM-PM dan mitra berkoordinasi secara daring dan luring. Kegiatan daring dilakukan dengan 
menggunakan Whattapps dan googlemeet untuk proses koordinasi. Kegiatan yang bersifat luring dilaksanakan dengan tatap muka. Pelaksanaan sosialisasi dengan mematuhi protokol kesehatan dengan mencuci tangan, menggunakan handsanitizer, memakai masker dan faceshield, dan menjaga jarak. Pelatihan dilakukan di ruang terbuka dan luas.

Implementasi PKM-PM ini dilakukan dengan metode partisipatif dengan pendekatan sosial masyarakat (Nurhikmawati \& Yuhanna, 2020). Metode yang dilakukan oleh tim PKMPM adalah 1) Penyampaian materi pembuatan wooden home decoration. 2) Praktik pembuatan produk wooden home decoration. 3) Evaluasi tingkat pemahaman dan keterampilan karang taruna dalam membuat wooden home decoration.

Metode evaluasi yang dilakukan adalah 1) Mengevaluasi unjuk kerja peserta berupa produk wooden home decoration. 2) Memberikan kuesioner tingkat pemahaman peserta. 3) Menganalisis hasil angket pemahaman peserta. Indikator keberhasilan proram ini adalah 1) Adanya 7 produk hasil karya peserta pelatihan, 2) Adanya peningkatan pemahaman peserta sebanyak (kriteria baik dan sangat baik) sejumlah $>70 \%$.

\section{HASIL DAN PEMBAHASAN \\ Penyampaian materi pembuatan wooden home decoration}

Tahapan pertama yang dilakukan oleh tim PKM-PM adalah menyampaiakn materi pembuatan wooden home decoration. Pelatihan ini diawali dengan kegiatan pembukaan dan penyampaian materi secara oleh tim. Karang taruna putra sebanyak 10 orang sangat antusias dalam mengikuti pemaparan materi oleh tim. Karang taruna mendapatkan materi tentang sortasi limbah bilah kayu, cara membuat model/pola, cara pembuatan produk, cara finishing produk, dan potensi bisnis wooden home decoration. Tingkat kehadiran peserta sebnayak $100 \%$. Kegiatan ini dilakukan dengan menggunakan protokol kesehatan selama pandemi covid19.

Tahapan ini, tim juga menjelaskan tren budaya tanaman hias dan industri kreatif. Masyarakat mulai sadar dengan gaya hidup yang mengarah pada green living (Retno \& Yuhanna, 2018). Bilah kayu yang tidak terpakai bisa dibuat produk yang bernilai ekonomi (Cahyandari, 2007; Utomo et al., 2018). Tim PKM-PM juga memberikan beberapa contoh dan model wooden home decoration yang popular saat ini. Tahapan sosialisasi dan pemaparan materi sangat penting untuk memberikan gambaran program yang akan dilakukan (Widayanti \& Kristiawan, 2020)

\section{Praktik pembuatan produk wooden home decoration}

Tahapan kedua yang dilakukan oleh tim PKM-PM adalah praktik pembuatan wooden home decoration. Produk yang akan dibuat adalah rak bunga, rak hexagon dan rak dinding sebanyak 7 model. Limbah kayu jika dimanfaatkan dengan baik dan bernilai estetika, maka berpotensi menjadi bisnis baru (Dewanti et al., 2021). Adapun alat yang digunakan untuk membuat produk adalah gergaji, pasah listrik, palu, kuas dan penggaris. Bahan yang digunakan adalah limbah bilah kayu, triplek, paku, cat, politur dan amplas. Alat dan bahan ini sangat mudah ditemui di sekitar rumah dan di took bahan bangunan, sehingga mendorong minat karang taruna untuk membuat produk ini.

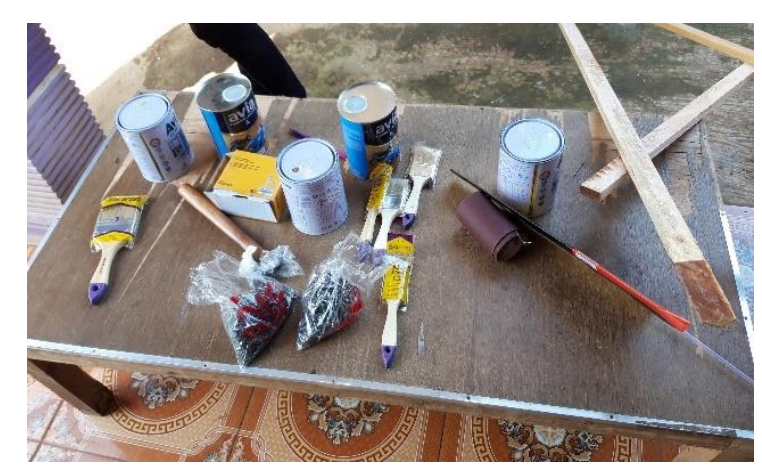

Gambar 2. Pembuatan wooden home decoration

Cara pembuatan wooden home decoration adalah sebagai berikut. 1) Mendesain produk wooden home decoration. 2) Membersihkan limbah kayu dan dipasah sampai halus dan sesuai ukuran. 3) Memotong sesuai desain dan ukuran. 4) Menggabung kayu sesuai desain. 5) Menghaluskan dengan amplas. 6) Melakukan finishing dengan cat, politur atau vernis.

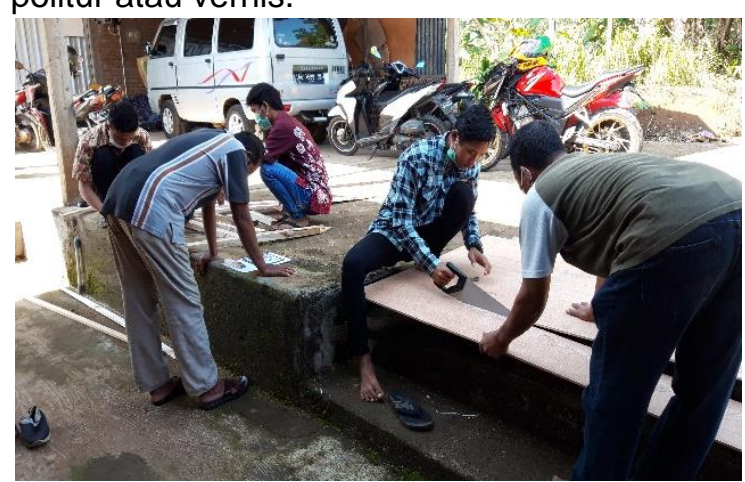

Gambar 3. Pemotongan bilah kayu dan triplek

Karang taruna Desa Setono sangat antusias dan aktif dalam bertanya dan mempraktikkan pembuatan wooden home decoration. Metode partisipatif dengan pendekatan sosial masyarakat sangat relevan 
untuk pelatihan ini. Peserta diberikan kesempatan untuk praktik langsung untuk menciptakan suatu produk. Tim PKM-PM memberikan pendampingan dan melayani pertanyaan peserta dengan baik. Tim juga melakukan sharing session dengan peserta terkait pemilihan model dan metode finishing yang dilakukan. Sinergisitas ini sangat diperlukan agar pelatihan berjalan lancar, dan materi dapat diserap oleh peserta. Peserta berharap untuk adanya suatu bengkel workshop dan showroom hasil wooden home decoration. Fasilitas ini memang sangat membantu pengrajin dalam mengembangkan usahanya (Putri \& Julistiono, 2019)

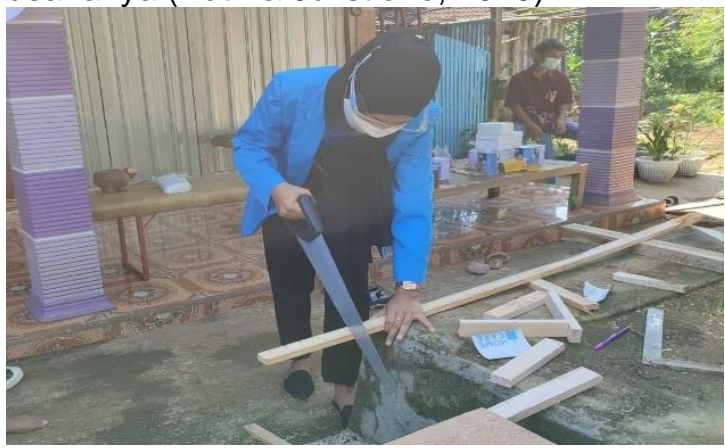

Gambar 4. Tim PKM-PM memberikan contoh pembuatan produk

Secara umum proses praktik pembuatan wooden home decoration ini berjalan lancar. Namun terdapat beberapa kendala yaitu peserta masih terpaut pada model yang diberikan oleh tim, peserta belum mengeksplorasi ide dan modifikasi model produk yang dibuat. Model dan desain sangat berpengaruh pada hasil pembuatan industri hasil homemade (Widyawan, 2015). Proses pengamplasan belum optimal, sehingga permukaan belum halus merata.

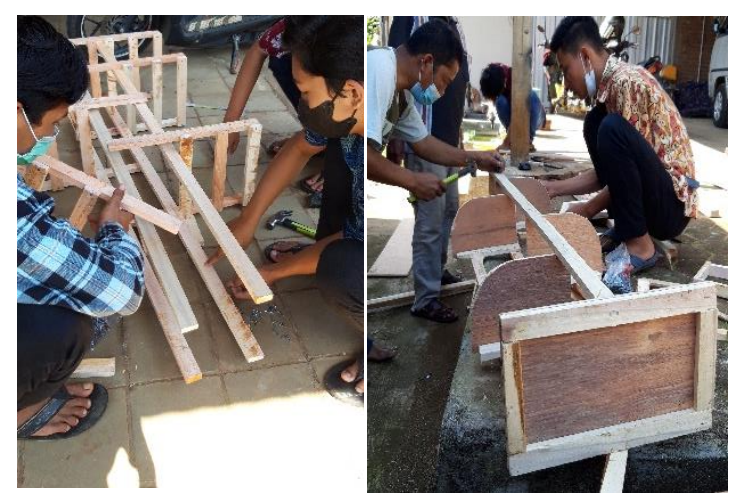

Gambar 5. Pembuatan wooden home decoration

Kendala lain yang dihadapi yaitu proses finishing dengan menggunakan politur lebih sulit dibandingkan dengan cat, karena tekstur kayu akan terlihat nyata. Rak kayu untuk pot bunga yang besar kurang kuat. Proses yang paling sulit menggunakan banyak waktu adalah sortasi limbah bilah kayu dan memperhalus dengan cara memasah kayu. Produk berupa rak hexagon dan rak dinding belum begitu sempurna, perlu pelatihan ulang untuk membuat produk tersebut.

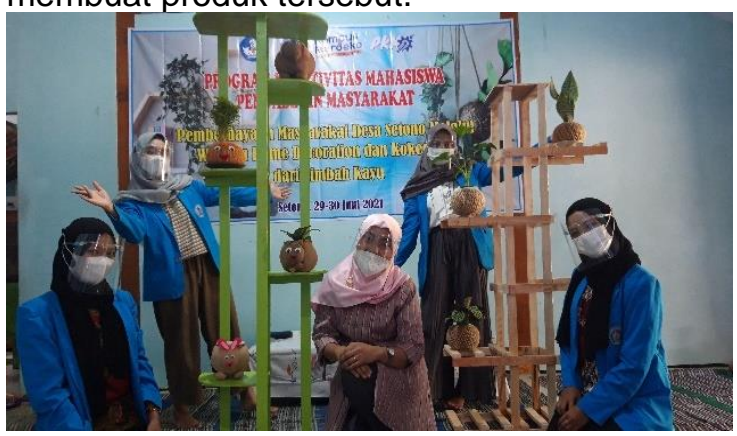

Gambar 6. Hasil wooden home decoration

TIM PKM-PM juga memberikan materi peluang bisnis dari wooden home decoration. Limbah bilah kayu ini pada awalnya hanya dihargai Rp. 2.000, per batang. Setelah dibuat menjadi produk rak bunga dengan modal awal Rp. 25.000, dapat laku dijual dengan harga 80.000-100.000. Rak Hexagon dengan modal Rp. 10.000,- mampu dijual dengan harga $\mathrm{Rp}$. 40.000,-. Keuntungan yang diperoleh cukup menjanjikan. Pangsa pasar juga dapat dengan mudah dijangkau dengan memanfaatkan penjualan langsung, sosial media, dan platform e-commerce. Penggunaan internet dengan sistem penjualan online saat ini memang dirasa sangat efektif. Penjualan online dapat memperluas pemasaran (Arifianto et al., 2018) Tren berkebun saat ini memberikan peluang bisnis untuk penjualan produk wooden home decoration ini.

\section{Ketercapaian hasil PKM-PM}

Berdasarkan indikator, keberhasilan program dilihat dari dua aspek yaitu produk dan pemahaman peserta. Hasil pelatihan pembuatan wooden home decoration diperoleh hasil bahwa terdapat 7 model produk yang dibuat oleh karang taruna Desa Setono. Produk tersebut adalah 4 rak kayu dan 3 rak dinding berbentuk kotak dan hexagon. Produk rak secara kualitas tergolong baik dan layak untuk dijual dan digunakan. Namun, perlu lebih memperhalus tekstur kayu, meningkatkan mutu rak dinding dan rak hexagon. Tim PKM-PM juga membuat katalog produk hasil pelatihan.

Indikator kedua adalah peningkatan pemahaman peserta. Berdasarkan angket yang berisi 10 pertanyaan diperoleh data bahwa sebanyak 6 orang dengan kriteria pemahaman materi sangat baik, 2 orang baik dan 2 orang cukup baik. hasil presentase pemahaman dapat dilihat pada gambar 7 . 


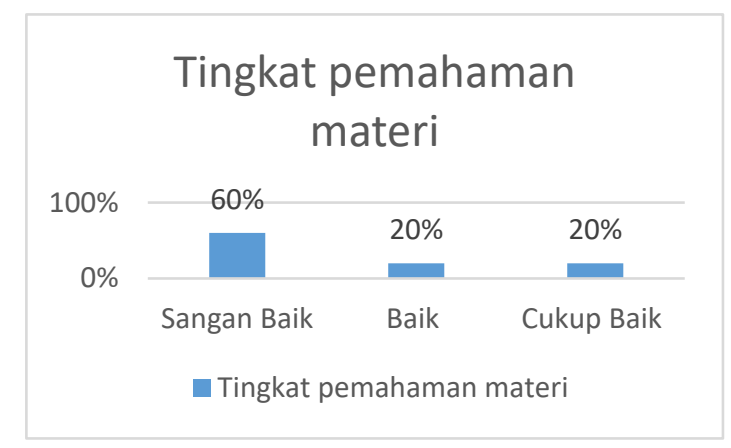

Gambar 7. Histogram tingkat pemahaman materi

Gambar 7 menujukkan bahwa secara klasikal tingkat pemahaman dengan kriteria sangat baik dan baik adalah $80 \%$. Hal ini memunjukkan bahwa peserta pelatihan ini paham terhadap materi yang diberikan. Upaya selanjutnya adalah tim PKM-PM akan terus melakukan pendampingan, monitoring dan evaluasi selama 3 bulan ke depan. Peserta berkomitmen untuk terus melanjutkan kegiatan pembuatan wooden home decoration ini, dan mengembangan bisnis industri kreatif.

\section{SIMPULAN DAN SARAN}

Simpulan dari PKM-PM ini adalah 1) limbah penggergajian kayu dapat digunakan menjadi Wooden Home Decoration sebanyak 7 model yang bernilai jual tinggi dan tidak mengganggu lingkungan. 2) Adanya peningkatan pemahaman karang taruna Desa Setono dalam membuat Wooden Home Decoration dari limbah pengergajian kayu sebanyak $80 \%$.

Saran untuk kegiatan selanjutnya adalah tetap fokus pada pengolahan limbah untuk dijadikan produk yang bernilai jual. Karang taruna Desa Setono agar lebih termotivasi dan melanjutkan rintisan industri kreatif ini. Tim menginovasi dan mendesain lebih banyak model yang sesuai dengan tren pasar gardening saat ini.

\section{UCAPAN TERIMAKASIH}

Ucapan terimakasih penulis sampaikan kepada Belmawa kemdikbudristek yang telah membiayai kegiatan ini dari skim PKM-PM tahun 2021. Penuis juga mengucapkan terimakasih kepada karang taruna Desa Setono yang telah bersedia berpartisipasi dalam kegiatan ini.

\section{DAFTAR RUJUKAN}

Abednego, S., \& Pramudita, D. (2017). ANBOTTLE : Lampu Dekoratif dari Bahan Limbah Kayu dan Botol.

Arifianto, E. Y., Santosa, P. B., \& Kurniawati, S. (2018). Perancangan E-commerce untuk
Mengembangkan Pemasaran dan Pemesanan Produk Industri Kreatif Kerajinan Kayu. Seminar Nasional IENACO, 575-582.

Cahyandari, D. (2007). Pemanfaatan Limbah Kayu Sebagai Bahan Dasar Pembuatan Papan Partikel. Jurnal Unimus, 5(1), 2634.

Dewanti, F. D., Sulistyono, A., \& Koentjoro, Y. (2021). Pengembangan dan peningkatan berbasis limbah kayu jati kualitas usaha kerajinan Info Artikel Abstrak indah atau berfungsi, atau bahkan memiliki fungsi dan juga keindahan. Seni fungsi antara lain sebagai media ekspresi, dekorasi , benda terapan, dan Pr. 4(36), 118-127. https://doi.org/10.33474/jipemas.v4i1.910 8

Eskak, E. (2014). PEMANFAATAN LIMBAH RANTING KAYU MANIS ( CINNAMOMUN BURMANII ) UNTUK PENCIPTAAN SENI KERAJINAN PENDAHULUAN Secara umum kayu manis ( Cinnamomum burmanii) dikenal sebagai salah satu jenis dari rempahrempah atau bumbu masakan dan minuman tradisional. Nama. Dinamika Kerajinan Dan Batik, 31, 65-74.

Janah, F. M. (2019). Pemanfaatan Limbah Plastik Dan Limbah Kayu Sebagai Bahan Komposit Kayu Plastik Untuk Melapisi Produk Interior Dan Eksterior Pada Rumah Tangga. 1-5. https://doi.org/10.31219/osf.io/wvhab

Nurhikmawati, A. R., \& Yuhanna, W. L. (2020). Pemberdayaan Kelompok Koperasi Wanita Putri Jati Emas Melalui Pembuatan Houseware Dari Limbah Vinil. Panrita Abdi - Jurnal Pengabdian Pada Masyarakat, 4(3), 273. https://doi.org/10.20956/pa.v4i3.7472

Purwanto, D. (2009). Analisa Jenis Limbah Kayu Pada Industri Pengolahan Kayu Di Kalimantan Selatan. Jurnal Riset Industri Hasil Hutan, 1(1), 14. https://doi.org/10.24111/jrihh.v1i1.864

Purwanto, D. (2011). Pembuatan balok dan papan dari limbah industri kayu. Jurnal Riset Industri, V(1), 13-20.

Putri, C. I., \& Julistiono, E. K. (2019). Fasilitas Kerajinan Limbah Kayu di Blora. Jurnal Dimensi Arsitektur, 7(1), 329-336.

Retno, R. S., \& Yuhanna, W. L. (2018). Implementasi green living berbasis scientific inquiry pada pembelajaran ipa terhadap kinerja ilmiah mahasiswa. Premiere Educandum: Jurnal Pendidikan Dasar Dan Pembelajaran, 8(1), 31. https://doi.org/10.25273/pe.v8i1.2087

Rochayati, N., Pramunarti, A., Mas'ad, M., \& 
Suryani, S. (2018). Pemberdayaan Perempuan Pedesaan Melalui Pelatihan Pengelolaan Sampah Rumah Tangga. SELAPARANG Jurnal Pengabdian Masyarakat Berkemajuan, 1(2), 9. https://doi.org/10.31764/jpmb.v1i2.456

Utomo, T. P., Suyasa, I. N., \& Haryanto, E. S. (2018). Pengembangan Desain Produk Kerajinan Berbahan Limbah Kayu Di Klaten. Abdi Seni, 9(1), 37-42. https://jurnal.isi-

ska.ac.id/index.php/abdiseni/article/view/ 2454

Wahyudi Arfianto, A. E., \& U. Balahmar, A. R. (2016). Pemberdayaan Masyarakat Dalam Pembangunan Ekonomi Desa. JKMP (Jurnal Kebijakan Dan Manajemen Publik), 2(1),

53. https://doi.org/10.21070/jkmp.v2i1.408

Widayanti, F. D., \& Kristiawan, I. (2020). Pemberdayaan Pemuda dalam Pengelolaan Limbah Kayu Bernilai Ekonomis di Desa Kemantren Kecamatan Jabung. Sasambo: Jurnal Abdimas (Journal of Community Service), 2(1), 19. https://doi.org/10.36312/sasambo.v2i1.17 8

Widyawan, V. (2015). Pengembangan Industri Pengolahan Kayu Sebagai Upaya Pengembangan Ekonomi Lokal (Studi Pada Desa Sukorejo, Kecamatan Bojonegoro, Kabupaten Bojonegoro). None, 3(7), 1105-1110. 